\title{
Impact of Dominican and Franciscan Monastery Complexes on Urban Planning Development in the Livonia Confederation and the State of the Teutonic Order
}

\author{
Silvija Ozola, Riga Technical University
}

\begin{abstract}
The Augustinians (Latin: augustiniani) lifestyle was determined by the Regula Sancti Augustini, developed in compliance with St. Augustin's concept, created in the $8^{\text {th }}$ century, but supplemented in the $9^{\text {th }}$ century with a condition that monks have to live together in monasteries (Latin: abbatia). Augustinians preached that the power of the church is dominant over the secular and invited to eradicate the ones who thought in a different way. In the first half of the $\mathbf{1 2}^{\text {th }}$ century, Augustinians founded monasteries' schools for sons of noble families. In cities, there were no places for worship. Inhabitants had to travel far in order to reach a monastery. In 1183, in the nearby Bexhövede Village foundations were laid for St. John the Baptist's Church. The church was consecrated by Bremen Archbishop Siegfried I (around 1132-1184). Albrecht von Buxthoeven (1165-1229), who participated in the church foundation, started here his clergy journey, but, after becoming Bishop of Riga (Latin: Adalbertus Canonicus Rigensis), he laid the foundation-stone for Riga Cathedral on July 25, 1211.

In 1214, Augustinian Canon Domenico di Guzmán (1170-1221) and some monks in Toulouse founded the religious organization the Order of Preachers (Latin: Ordo Praedicatorum) or the Dominican Order. In Rome on the Aventine Hill the Dominicans (Latin: praedicatores) main church- Basilica of Santa Sabina (422-432) was consecrated. Dominicans, which were not allowed to own secular properties, did not look for seclusion. In cities, monasteries were established and care of the poor was taken. It was considered that monasteries did not need any riches. Monks had to provide their subsistence with work, but if it was not sufficient, they had to ask for alms. Dominican monasteries built for the Baltic land subjugation were the place of residence for monks in order to bring urban population to Christianity and to promote their education.

In 1211, in Akona the Italian poet Giovanni Francesco di Pietro di Bernardone (1182-1226) started his missionary work. He, following the call to become a Catholic monk, founded the Franciscans Order and wrote the Regula Bulata (1209), which Pope confirmed in 1223. On March 18, 1212 Franciscus Assisiensis and Clara Assisiensis (1193-1253) founded the poor sisters' Order of Saint Clare (Latin: Ordo Sanctae Clarae). People obtained a spiritual power supply, but the monks-beggars' monasteries in medieval cities became important. Churches became accessible to inhabitants of city. Franciscan monasteries in the Baltic lands were places of residence for monks in order to bring the urban population to Christianity.
\end{abstract}

Keywords: Augustinians, Dominicans, Franciscans, Livonia, monastery church, State of the Teutonic Order

Introduction

The Holy Roman Emperor (1133-1137) Lothar III (Lothar von Supplinburg) used as a sample the Neumünster Novum Monasterium Church (1127) with the transept and a massive tower (Fig. 1), founded by Oldenburg and Holstein bishop Saint Vicelinus (1086-1154), and established under the Bremen Metropolis subjugation the Segeberg Augustinian Monastery (German: Augustinerkloster Segeberg; $1134-16^{\text {th }}$ cent. $2^{\text {nd }}$ half) near the Port of Bremen (German: Bremerhaven). The building complex included St. Mary's Church (1156) with a high tower (Fig. 2) [4, 335]. Around 1500 before reformation, Augustinians founded a monastery in Lemsal (Latvian: Limbaži) [1, 200].

Dominicans were not allowed to build churches taller than 30 feet, creating stone arches, except above the altar part and scarcity. People in cities built churches, rebuilding even sheds. Dominicans' homes were modest, and the place for worship was also arranged in the bedroom [8, 205]. Bishop of Riga Albrecht initially was envisaged to be built Riga
Cathedral in laconic building forms (Fig. 3). Riga developed on the bank of the Rìdzina (Rising) River. Later Škūnua-Skārṇu Street was created. First of all, there were built four yards one after the other - for the bishop, Bothers of the Sword, Canonical Chapter (later the buildings of the Franciscan monastery) and merchants. In 1206, in the place of the Large Guild (Latvian: Lielā Gilde), 6 Amatu Street the bishop's St. Mary's (eccesia beate Marie) Cathedral, which, possibly was a wooden building (burnt down on March 4, 1215), together with the Canonical Chapter in the same building or in its annex (monasterium). In Riga centre next to the bishop's first yard the Brothers of the Sword St. Georgi's yard was built, and Germans established secular and spiritual power centres, political and economic diarchy and a fortified principal military economic base for the expansion in the Baltics. Defensive walls (murum civitatis), mentioned for the first time in 1207, made the town unassailable, but in summer 1208 they were raised. Between 1211 and 


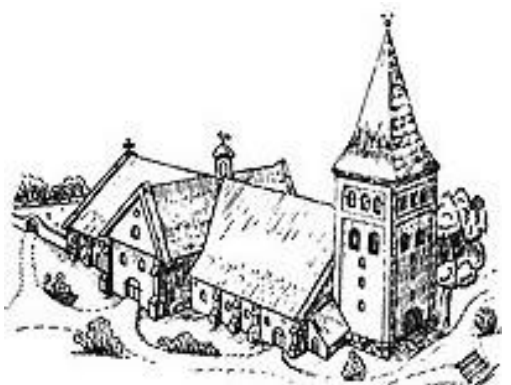

Fig. 1. The overview drawing of Neumünster Novum Monasterium Church.

[ http://www.vicelin-kirche-nms.de/fileadmin/_processed_/csm_ geschicht kirche 00c22cd821.jpg]

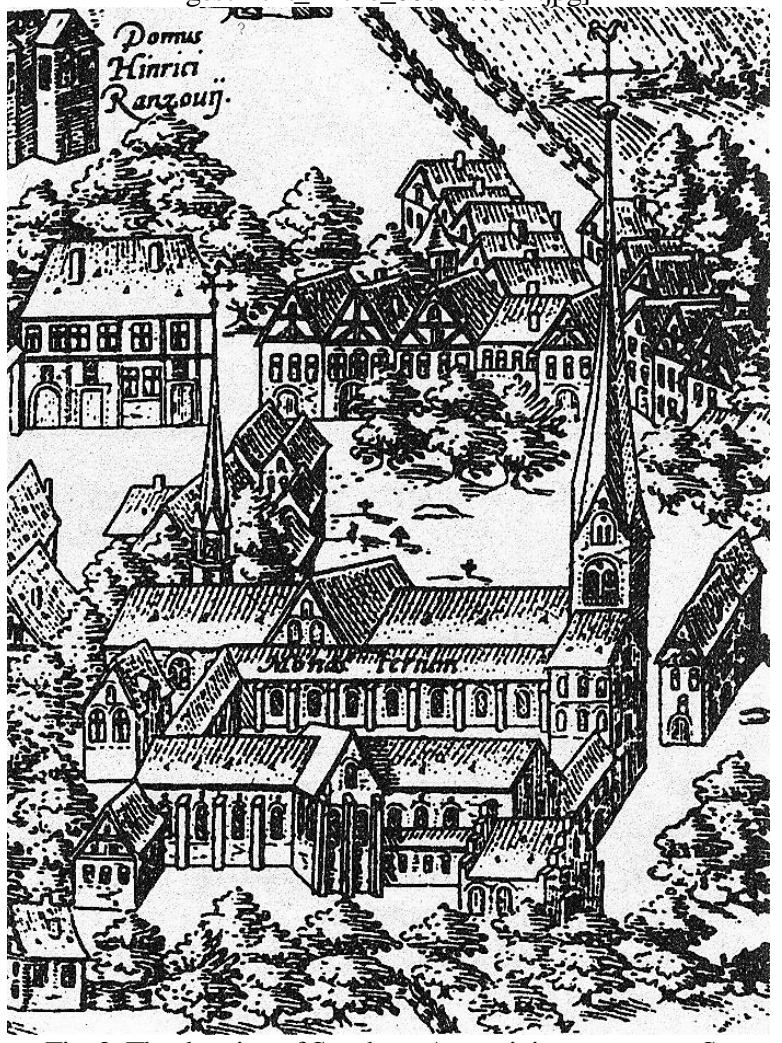

Fig. 2. The drawing of Segeberg Augustinian monastery St. Mary's Church [4,335]

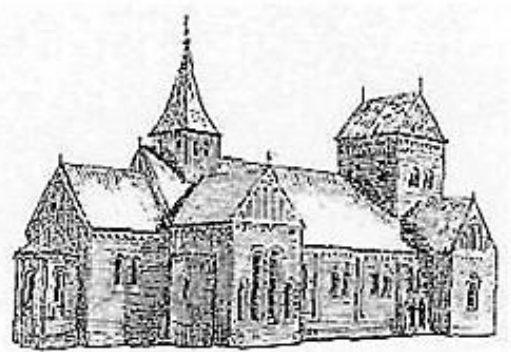

Fig. 3. Wilhelm Neumann. The reconstruction drawing of St. Mary's Cathedral in Riga [online 19.06.2017, source: http://www.doms.lv/resources/rekonstrukcija01_350.jpg]

1215 on the outside of defensive walls the construction of second bishop's yard, as well as the Riga St. Mary's Cathedral (Latvian: Rīgas Doms) and at least an abbey for the Canonical Chapter, which lifestyle was determined by the Regula Sancti Augustini, was started $[1,252]$. In the $13^{\text {th }}$ century, the
Cathedral's congregation room was built. On the south side cloisters surrounded the cloister courtyard, but the eastern block was built for the complex. On the ground floor there was a store room and the Chapter Hall, but on the top floor - bedrooms. Later the south block with the kitchen and household rooms, and the western block for the Latin School were built [11, 31]. The fourth - north block was also planned. Till 1547, the three-storey square planning tower in the middle of the western transept (14 ${ }^{\text {th }}$ cent.) was covered with a pyramidal steeple. The front-hall plan confirms the initial intention to build two towers on the western façade [1, 254-255]. In 1425 the pope awarded Dominicans the rights to real estate. Next to the defensive wall the planning of the Riga Archbishopric Centre was made up of two urban structures. The Riga Bishop's second yard perimeter structure with the sacral building, included in it, reminded of the Roman Bishop's residence solution on the Lateran Hill in Rome, but the Riga Cathedral complex consists of the abbey and the Cathedral. In the Old Town of Bremen Dominicans built the Monastery of St. Catherine (German: Dominikanerkloster St. Katharinen; 1225). In Lübeck, commemorating the victory in the Bornhöved Battle, which happened on Mary Magdalena's Day on July 22, 1227, the Monastery of St. Mary Magdalena (German: Maria-MagdalenenKloster; 1229) was founded northwards from the Old Town, where a small hall church was built. After the fire in 1276 the Castle-monastery (German: Burgkloster; after 1276-1401) was built again and the abbey church was named after Mary Magdalena. The building was rebuilt and extended on multiple occasions, and around 1399-1401 the basilica obtained a new triple-nave room (German: Hallenchor) and a representative façade directed towards Castle (German: Burgstraße) Street. In 1236, in Hamburg not far from Franciscan St. Marien-Magdalenen-Kloster Dominicans founded the Monastery of St. John (German: Dominikanerkloster St. Johannis; 1236-1529). The spiritual power centre was established.

In Assisi the construction of San Rufino Cathedral (Italian: Cattedrale di Assisi, Cattedrale di San Rufino di Assisi; 1140-1253) [12, 246], designed by architect Giovanni da Gubbio for the martyr, Bishop Rufino ( $3^{\text {rd }}$ cent.), was started. Franciscus Assisiensis was canonized. Pope (1227-1241) Gregorius IX consecrated a high altar in San Rufino Cathedral, where Franciscus Assisiensis was worshipping. On July 17, 1228 in Sacro Convento (Italian: Il Sacro Convento di San Francesco in Assisi) the foundation stone was laid for the single-nave Basilica of St. Francis of Assisi (Italian: Basilica Papale di San Francesco, Latin: Basilica Sancti Francisci Assisiensis) with the transept. The visible part of the two-storey building was made on the hill, but the lower part with chapels and crypts was enclosed by 


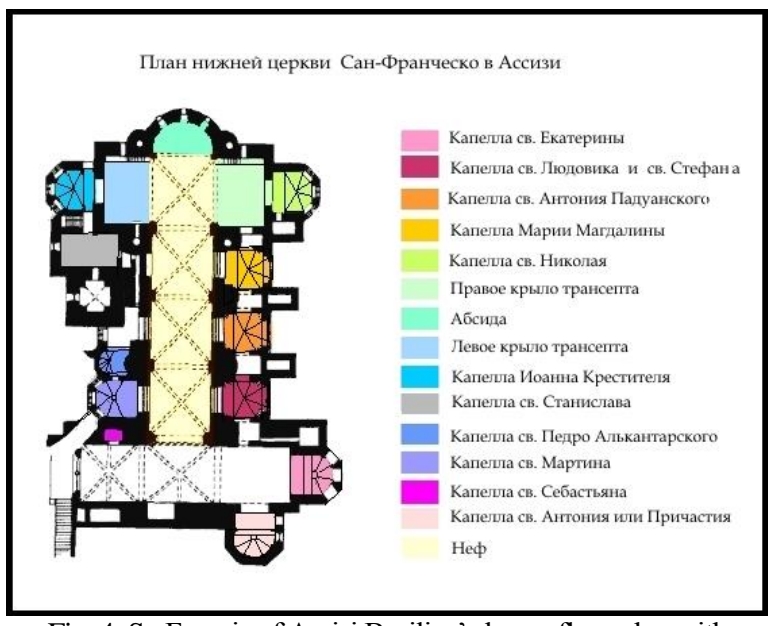

Fig. 4. St. Francis of Assisi Basilica's lower floor plan with chapels at the transept's ends, on right and

left sides of the nave and at the nave's west end. 2007

[online 19.06.2017, https://upload.wikimedia.org/

wikipedia/commons/a/a5/План_нижней_церкви_Ассизи.jpg]

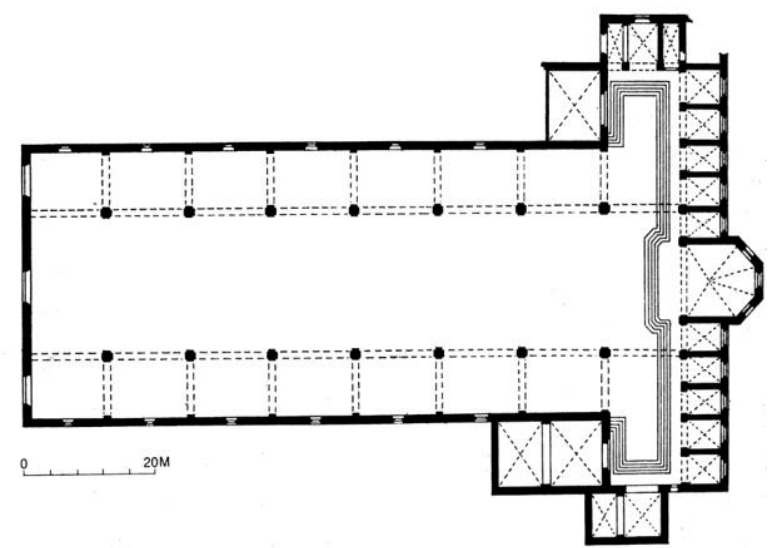

Fig. 5. Italian architect, sculptor Arnolfo di Cambrio (ap 12401300/1310). The T-type plan of Franciscan monastery Basilica of the Holy Cross in Florence

[online 19.06.2017, http://www.oberlin.edu/images/ Art336/366-0402.JPG]

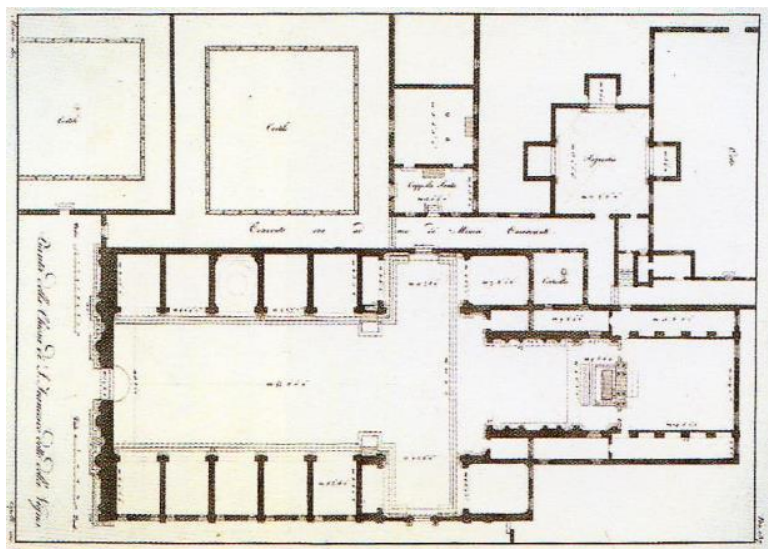

Fig. 6. Italian architect, sculptor Jacopo d'Antonio Sansovino (1486-1570). The plan of Franciscan monastery San Francesco della Vigna Church in Venice. 1534. [online: 26.06.2017, http://www.churchesofvenice. co.uk/sanfrandellav14.jpg] the monastery (Fig. 4). The main Franciscans Church obtained the status of Major basilica (Latin: Basilica maior).

In Florence, on May 12, 1294 instead of the oldest church the construction of the principial Franciscan church in Italy, possibly designed by architect, sculptor Arnolfo di Cambio (1240-1300/1310), was started. The T-type plan of Basilica of the Holy Cross (Italian: Basilica di Santa Croce; 1294-1385) (Fig. 5) is similar to the plan of the oldest St. Peter's Basilica in Rome. On the left side of the main nave there are Galileo Galilei and Desiderio da Settiganano's tombs, on the right side - Michelangelo Buonarroti, Vittorio Alfieri, Niccolo Machiavelli, Gioachino Rossini and Ugo Foscolo's tombs, but at the end - the choir, apse with the main altar and a line of chapels. In the northwest corner the Bardi di Vernio's Chapel with the crucifix, made by the sculptor Donatello (Donato di Niccolò di Betto Bardi; around 1386-1466), was placed. On the left of the main altar Bardi di Vernio, Pulci-Berardi, Ricasoli, Capponi, Spinelli's Chapels are situated, but on the right - Bardi, Peruzzi, Giugni, Calderini, Velluti's Chapels were created [17, 43]. In 1442, Pope (1431-1447) Eugenius IV consecrated the church.

In Venice, at 1223, Franciscans settled in existing monastery on the city's outskirts. On 28 April 1250 the cardinal Ottaviano or Attaviano degli Ubaldini (1214-1273), the first stone was laid for the new, second church, dedicated to Santa Maria Gloriosa. In the vineyard, which was donated by Marco Ziani in 1253, the monastery was made. Franciscans started to build a small church Santa Maria de' Frati Minori, consecrated in 1280 . With the increasing role of the Franciscans, a new building for the church was required, and, begun in 1330 by an unknown architect. In 1396, the campanile, the second tallest in the city after that of San Marco, was completed by architects Jacobello dalle Masegne (1350-1409) and Pier Paolo (till 1383-1417) dalle Masegne. May 27, 1492 the Basilica di Santa Maria Gloriosa dei Frari was consecrated. On August 15, 1534 instead of the former chapel, the foundation stone was laid for San Francesco della Vigna Church (1253, 1534-1554) with an extended chancel (Fig. 6), designed by the architect, sculptor Jacopo d'Antonio Sansovino (1486-1570) from Florence.

Previous researches on monastery churches in Western Europe: in Georg Dehio's and Gustav von Bezold's "Kirchliche Baukunst des Abendlandes" [3], issued in Stuttgart 1887-1901, graphical materials of cult buildings - plans, cuts, façade drawings have been collated, In Rolf Toman, Alan Bednorz and Barbara Borngässer's book "Cathedrals and Churches of Europe" (2015) [12] broad information on churches and cathedrals in Europe has been included. 


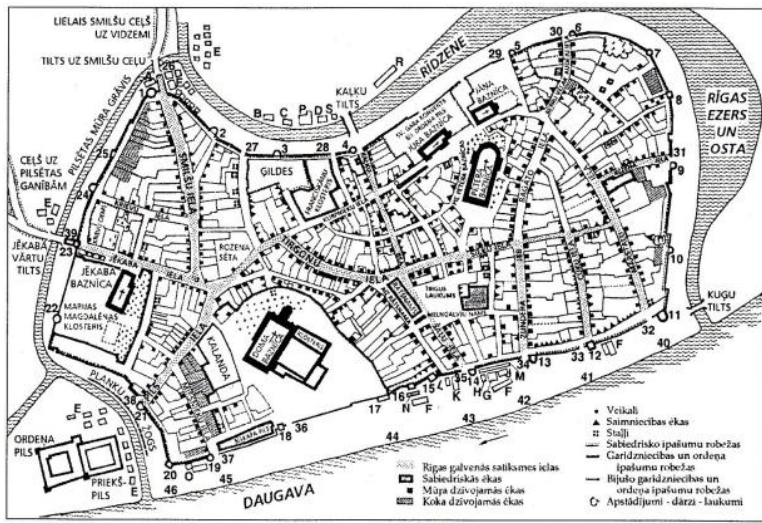

Fig. 7. The Riga Archbishopric Centre buildings in Riga plan around 1500 [11, 154-155]

a

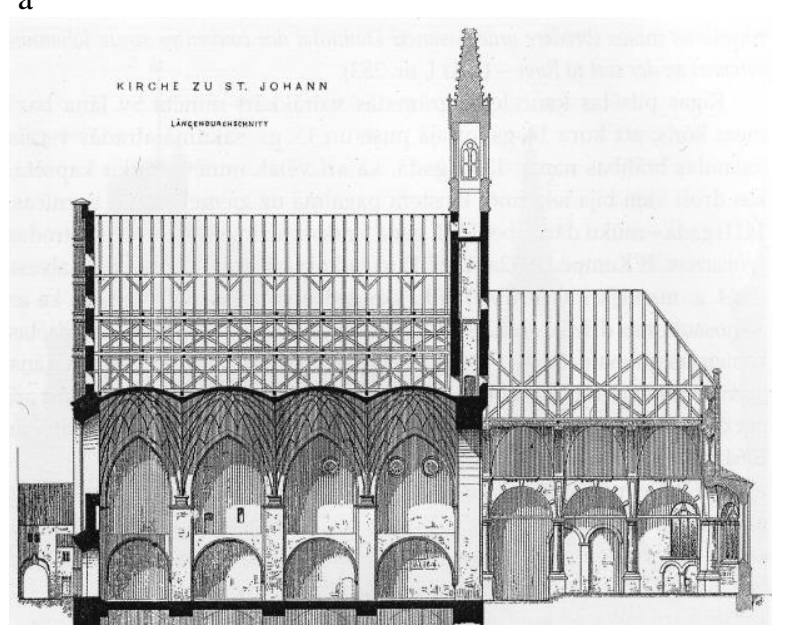

b

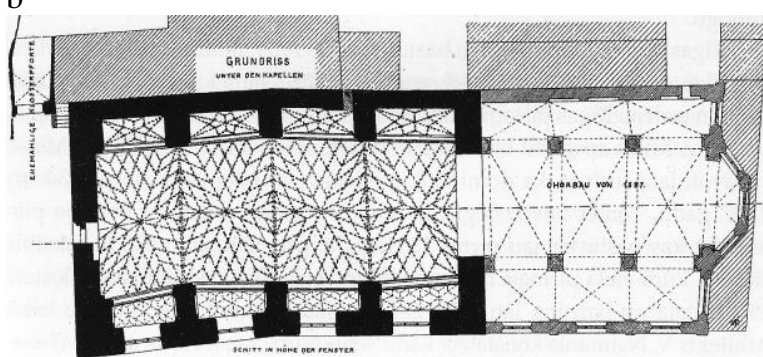

Fig. 8. Wilhelm Neumann. Riga St. John the Baptist Church: $\mathrm{a}-\mathrm{a}$ longitudinal section, $\mathrm{b}$ - a plan. 1892 [1, 270-271]

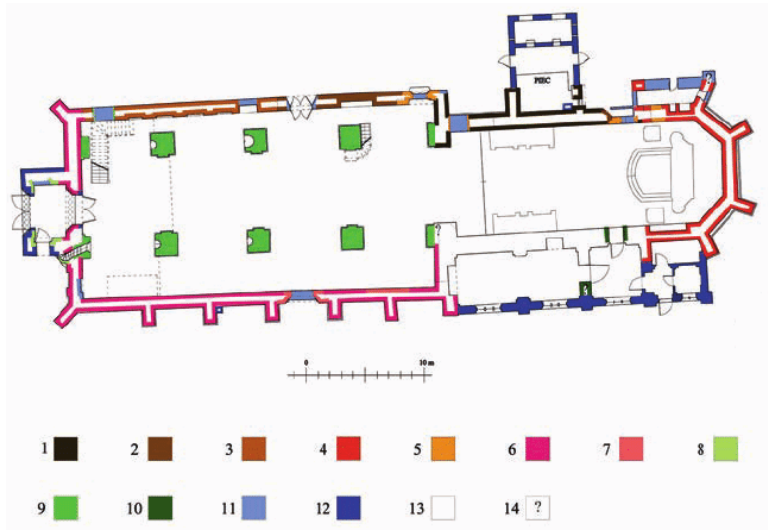

Fig. 9. Development periods of

Dominican monastery Kulm St. Peter and

St. Paul's Church plan. 1907 [9]
Previous researches on monastery churches in Livonia: the famous fortress researcher in the Baltics, Estonian historian of art, Professor of Tartu University Dr. phil. Armin Tuulse (1907-1977) has collated the data on abbey buildings in Estonia and Latvia in the edition "Die Burgen in Estland und Lettland" (1942) [13]. The outstanding Latvia historian, prof. emeritus Dr. Indrikis Šterns (1918-2005) of Muhlenberg College, US has included the information in the monographs "Latvijas vēsture. 1290-1500" /History of Latvia. 1290-1500/ and "Latvijas vēsture. 11801290. Krustakari" /History of Latvia 1180-1290. Crusades/ in the edition "Señ̄ Rìga" /Ancient Riga/, issued by Latvia Institute of History. Some information can be found in the article "Daži mazāk pazīstami seno mūra celtnu fragmentu atradumi Vecrīgas apbūve“" /Findings of a few less known ancient stone building fragments in Old Riga construction/ (2001) [5] by the Science Academy Honorary Doctor, architect Gunārs Alfrēds Jansons (1928-2013) on St. Catherine's Church and findings in the territory of the Franciscan Abbey. The encyclopaedia "Latvijas 12. gadsimta beigu17. gadsimta vācu pilu leksikons" /Lexicon of late $12^{\text {th }}-17^{\text {th }}$ century German Castles in Latvia/ (2004) [2] compiled by archaeologist prof. Dr. habil. hist. Andris Caune and Dr. Ieva Ose has been published into series of books "Latvijas viduslaiku pilis" /Medieval Castles in Latvia/, but "Latvijas viduslaiku müra baznīcas. 12. gs. beigas - 16. gs. sākums" /Medieval stone churches in Latvia . Late 12th cent-early 16th cent./ (2010) [1] is an encyclopaedia, which includes broad information. Prof. Dr. hist. Ilgvars Misāns and asoc. prof. Andris Šnē of Latvia University History and Philosophy Faculty have prepared materials for seminars in Medieval History of Western Europe "Klosteris, pils un pilsēta" /Abbey, Castle and City/ (2004) [8]. In the book "Rìgas dievnami. Arhitektūra un māksla" /Churches of Riga. Architecture and Art/ joint the article "Svētās Katrīnas baznīca" /St. Catherine's Church/ by Dr. arch. Jānis Zilgalvis (b. 1955) and Marina Levina (b. 1954), architect of National Inspectorate for the Protection of Monuments, has been included (2007) [16]. Previous researches on monastery churches in Prussia: historian Zbigniew Nawrocki's publication "Pofranciszkański kościót NMP w Toruniu. Próba rekonstrukcji dziejów budowy" (1966) [9] dedicated to the theoretical reconstruction of Torun Franciscan Church, and the specialist of architecture and art history Piotr Samól has analysed building of the Culm Dominican Church in the research "Architektura kościoła podominikańskiego $p w$. św. św. Piotra i Pawła w Chetmnie w świetle badań z lat 2010-2013" (2013), but Dr. Liliana Kranz-Domasłowska (b. 1954) has included the information on abbey churches in the 


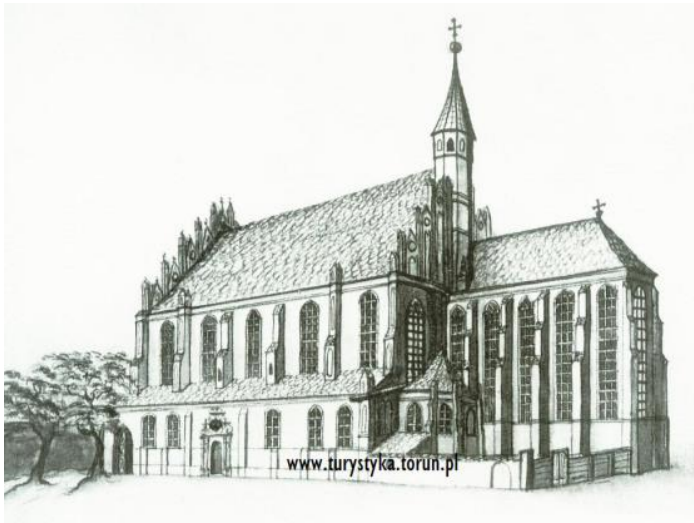

Fig. 10. The overview of Dominican monastery St. Nikolay Church in the New Town of Thorn. 1743 [10]

research about double cities "Double cities in the Teutonic state on the example of Torun" (2013) [6].

Research problem - the impact of medieval monasterys' complexes on the origins of Livonian and Prussian urban environment and building formation has been studied insufficiently. Research novelty the identity of Livonian and Prussian monastery churches' architecture and impact of fortified building complexes on the urban environment formation origins in the Baltic during the $13^{\text {th }}-14^{\text {th }}$ century have been analysed in regional and European context. The goal of the research - analyse the peculiarities of architecture and planning of monastery churches, as well as the influence of monastery complexes on the establishment of the Teutonic Order's fortified power centres and town planning of Livonia and Prussia during the $13^{\text {th }}$ and $14^{\text {th }}$ centuries in order to determine the common and different characteristics. Main methods applied - inspection of the buildings in nature, analysis of archive documents, projects and cartographic materials.

\section{The Dominican monastery church planning and structure in the Livonia confederation and the State of the Teutonic Order}

On September 8, 1234, Bishop of Riga (1229-1253)

Nikolaus von Nauen (Latin: Nicolaus Canonicus Rigensis) presented the first Riga bishop's yard with the stone residence, which possibly damaged in the fire on March 4, 1215, and the plots of land belonging to it to Dominican monks. They could settle down by the Rìdzinga (iuxta Rygam in antiqua civitate) and preach Christianity in Livonia [2, 392]. In the place of the Riga Bishop's first yard by defensive walls monks founded the Dominican monastery (1234), separated from the Order's properties by the frontier fortifications. The layout of the church and abbey buildings (Fig. 7) created a functional division for the fortified territory. In 1297, the church was mentioned for the first time as St. John the Baptist Church [1, 269-270] (Fig. 8a): its altar occupied partly the chapel's place of the residence, but the apse was made next to building's basics (Fig. 8b). Cloisters surrounded the courtyard.

In the Old Town of Kulm, which was placed in a geographically different place from the current Starogrod Chetmiński, Dominicans, possibly arriving in 1233, set up the abbey and started construction of St. Peter and St. Paul's Church (Polish: kościól św. Piotra $i$ św. Pawła $w$ Chetmnie) (Fig. 9), which was completed in the fourth quarter of the $13^{\text {th }}$ century. During the first building period the oratory of a low rectangular planning was made, from which a piece of the chancel's north wall has been preserved, but soon after that in the first quarter of the $14^{\text {th }}$ century the hall was built. During the second construction period instead of the partly destroyed oratory a square chancel was made (around 1330-1338), to which the closing behind the hexagon planning of the arch was decorated with blind windows in the plaster. Around 1340-1350 changes were made in the chancel, the abbey was increased and the church was linked to the abbey in three new places. In the third quarter of the $14^{\text {th }}$ century on the north side of the building a very narrow passage was made. From the third quarter of the $14^{\text {th }}$ century till 1390 during the third building period a two-storey construction volume was built, whose northern wall partly included the fragment of the hall built in the early $14^{\text {th }}$ century. The western façade of the triple-nave church was added to the asymmetric two-nave hall with six niches. Building was completed in three stages and the course of construction was conceptually changed. When the building was covered with the roof, the façade was supplemented with the corona part. In the late $14^{\text {th }}$ century building was not any longer developed, but the floor was covered with ceramic materials. In the early $15^{\text {th }}$ century the interior was painted [9]. Similarly, the Dominican monastery church was built in Thorn (Polish: Toruń), where the number of inhabitants and economic potential increased, and separate privileges were awarded to the Old and New Towns of Thorn. Both communities obtained complete independence, and each of them created their own legal, individual urban constructional formation. On April 2, 1263 Dominicans (Polish: Ojców Kaznodziejów $s$ w. Dominika) arrived in the New Town of Thorn and in the north-west corner of the both towns' border territory built monastery, financially supported by bishop of Kulm. Complex was supplemented with the biggest church in the New Town of Thorn - the triplenave St. Nikolay Church (Polish: kościót św. Mikołaja $i$ klasztor dominikanów; 1334, destroyed in the middle of the $19^{\text {th }}$ cent.) (Fig. 10) with a deep chancel (1334-1343), which had a polygonal closing and the sacristy built on the north side. The plan (1743) of Dominican monastery St. Nikolay Church includes mortuaries (Polish: św. Marii Magdaleny, św. Dominika, św. Róży, św. Jacka, św. Pana Jezusa, 


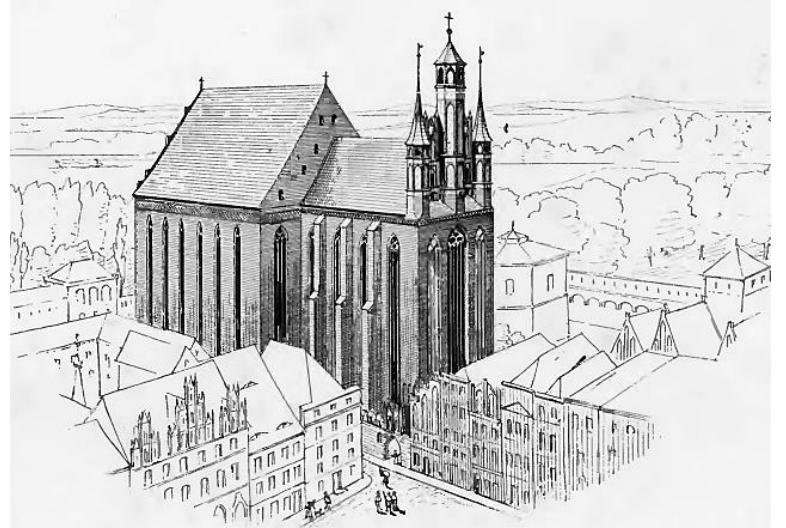

Fig. 11. Conrad Emanuel Steinbrecht. Overview of the Most Holy Virgin Mary's Church in the Old Town of Thorn. 1885 [10]

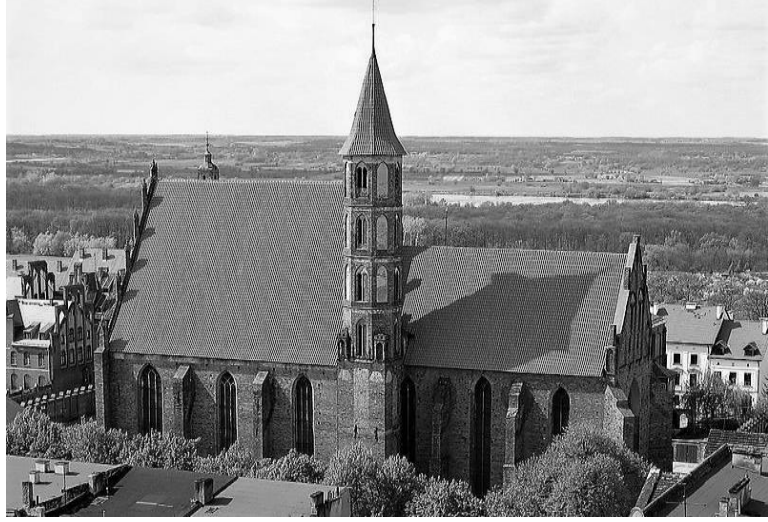

Fig. 12. Photographer Margoz. Overview of Franciscan monastery's St. Jacob and St. Nikolay's Church in the Old Town of Kulm. 2008 [online 19.06.2017,

http://upload.wikimedia.org/wikipedia/commons/e/eb/Che\%C5\% 82mno_Church_of_St_James_and_St_Nicholas.jpg]

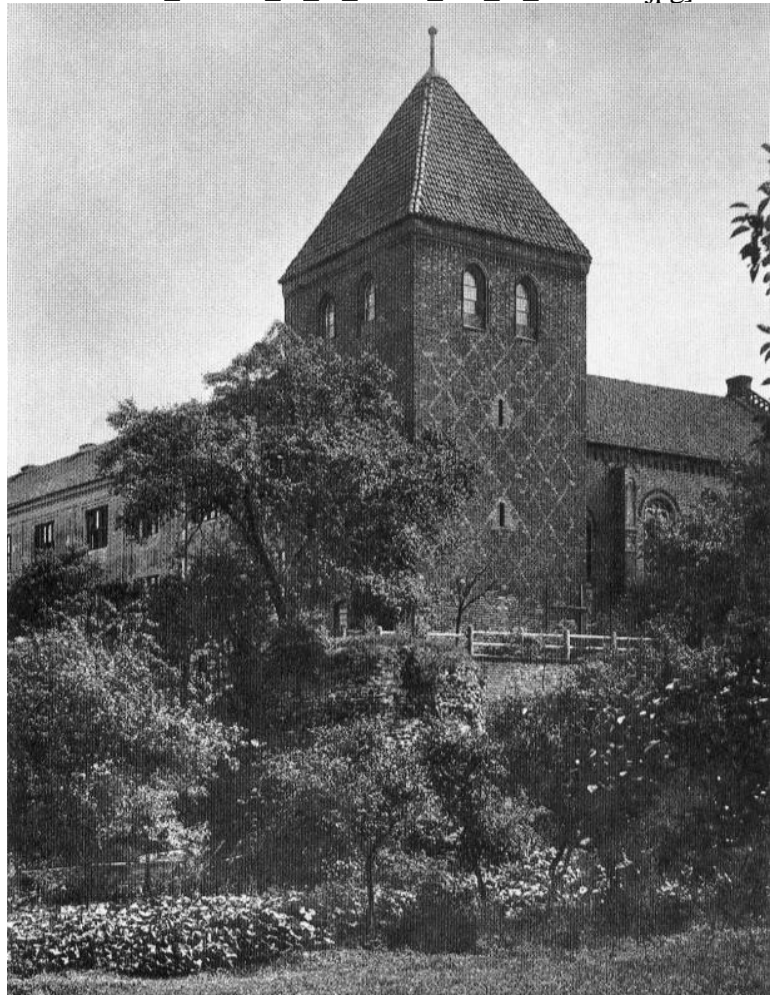

Fig. 13. The Franciscan monastery church close by the tower of Braunsberg defensive wall (the second half of the $14^{\text {th }}$ cent.) $[14,151]$ św. Barbary, św. Walentego, św. Józefa) [6]. In the Old Town of Elbing (Polish: Elblag) Dominican monastery was situated in the north-west corner of the defensive wall [6].

\section{The Franciscan monastery church planning and structure in the Livonia confederation and the State of the Teutonic Order}

The barefooted (barvîzen) or Minorites (Latin: minoritae, fratres minores) were forbidden to have either private property. The "Orders of beggarmonks" did not have any money, and they had to sustain themselves from voluntary donations, therefore initially people in cities built very simple churches, without applying architectonic forms typical to cathedrals. Franciscans also arrived in German lands. In the Old Town of Bremen the Monastery of St. John (German: Franziskanerkloster St. Johannis; 1225) was made, but in Hamburg St. Mary Magdalena's Franciscan Monastery (franziskanische St.Marien-Magdalenen-Kloster; 1227, 1235-1529). In 1225, a plot of land was allocated to Lübeck Franciscans from Magdeburg on the corner of Glockengießerstraße and Königstraße Streets in order to establish the Monastery of St. Catherine (Katharinenkloster; 1225-1531). Burgomaster Segebodo Crispin (?-1323) donated funds for the construction of the triple-nave St. Catherina's Basilica (German: Katharinenkirche, St. Katharinen zu Lübeck; 1300-1330). Northwards from the ambulatory (Latin: ambulatorium) - a circular passage around the choir - a chapel for his family (German: Familienkapelle, Crispinkalelle) was built. The chancel was made to the church with a polygonal closing (1329) and nave (1335).

In 1356 building work was completed. In Danzig by the market St. Catherine's Church (Polish: kościót św. Katarzyny; 1227-1239) was built, and Franciscans founded the Monastery of St. Brigitte's Sisters (German: St.Brigitten-Büßerinnen-Kloster $\quad \mathrm{zu}$ Danzig). Building of St. Brigitte's Church (St. Brigitten Kirche, poḷ: kościól św. Brygidy; around 1350) was started on the east side of St. Catharine's Church. In outskirts of Danzig the Franciscans monastery complex was created.

In Kulm land (Polish: Chetmno land, German: Kulmerland) Franciscans established the first convent (1239) towards north-west outside the Old Town of Thorn, where in the middle of the $13^{\text {th }}$ century the church of a rectangular planning was built. During the second stage of construction, an elongated chancel with a polygonal finish clung to the simple wall of the eastern end. The western part of the church had an asymmetric nave. During the $13^{\text {th }}-14^{\text {th }}$ century the church and abbey were extended (1350-1370): the Most Holy Virgin Mary's Church (Polish: kościót Wniebowzięcia Najświętszej Marii Panny, 1270-1300, 1557-1724, 1724-1821) was made with a nave, 


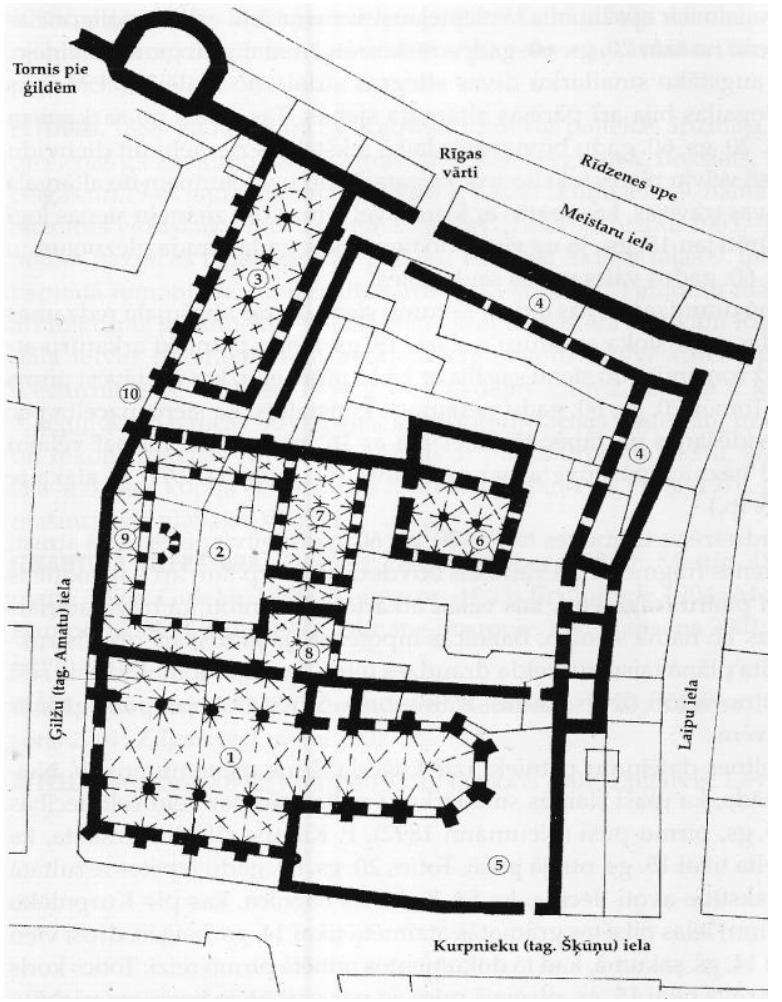

Fig. 14. Architect Gunārs Jansons (1928-2013).

The reconstruction drawing of Riga Franciscan monastery

St. Catherine Church plan: 1 - St. Catherine's Church (the second half of the $13^{\text {th }}$ cent.) with the annex of the choir (the $15^{\text {th }}$ cent.), 2 - courtyard, 3 - the first chapel (?) (the first half of the $13^{\text {th }}$ cent.), 4 - monastery stables (1330), 5 -cemetery of monastery (1396), 6 - old refectory (?), 7 - refectory with dormitory, 8 - the Canonical Chapter Hall, 9 - cloister, 10 - the Guild Gate (1336) [5,331]

covered with a ridged roof, without the main tower, whereas with an asymmetric hall and narrow windows. The construction volume of the chancel was supplemented with three towers of an octagonal planning, out of which the middle one was bigger (Fig. 11) [7].

Instead of the oldest church $\left(3^{\text {rd }}\right.$ quarter of the $13^{\text {th }}$ cent. $-1^{\text {st }}$ quarter of the $14^{\text {th }}$ cent.) in the western part of the Old Town of Kulm Franciscans built St. Jacob and St. Nikolay's Church (German: die Kirche St. Johanne des Taeufers und Johannes des Evangelisten, Polish: kościót św. Jakuba $i \quad s$ w. Mikołaja; 1326) of a triple-nave hall with a rectangular chancel (Fig. 12), to which on the south side there was a narrow tower of an octagonal planning. The main nave was covered with ribbed vaults, but the narrow side-passages - with star vaults. Buildings of the abbey were placed northwards from the church. In Braunsberg (Polish: Braniewo), surrounded with the defensive wall, Franciscans built the complex of the abbey's buildings in the north-west corner of the town (Fig. 13).

In Riga, Franciscans had already been since 1233 , but in 1258, the Monastery of St. Catherine (existed till reformation) with a stone house [1, 308] was mentioned for the first time. Cloisters separated the northern part of the courtyard with the oldest buildings - the chapel ( $1^{\text {st }}$ half of the $13^{\text {th }}$ cent.) and, possibly, the old refectory, from the cloister courtyard of St. Catherine's Church, built on the south side of the street in the late $13^{\text {th }}$ century or early $14^{\text {th }}$ century. A functionally diverse two-division plan was created. The refectory with dormitory and the Chapter's Hall closed the eastern side of the yard surrounded with cloisters. The monastery stone church was situated on the piece of land, most probably instead of the Canonical Chapter at the Riga defensive wall not far from the gate. Six octagonal pillars supported the valves of St. Catherine's Church triplenave hall with an elongated chancel. The gate of the abbey's entrance took into the yard, where in 1330 stables with the guard's pass were built [5, 124]. The city inhabitants used St. Catherine's Church, and in 1396 a cemetery was created nearby (Fig. 14) [1, 311].

Franciscan monasteries were in all towns of Riga Archbishopric: on the outskirts of Lemsal northwards outside the defensive wall a monastery $[1,198]$ and stone castle [1, 33] were built from 1466-1472. In Kokenhusen, the abbey, which clung to the inner side of the city's defensive wall, still worked in 1522 . On the east side of town not far from the defensive wall there was also a Catholic monastery Church with a tower [1, 33]. However, it is possible that during the Russian invasion in 1577 the abbey's buildings and church, whose tower was a significant orienteering, were destroyed [1, 167-168]. In Fellin (Estonian: Viljandi) the Franciscan monastery (14661472, closed in 1560) was founded near St. John and St. Clara's Church. Archbishop of Riga (1484-1509) Michael Hildebrand (Latin: Michael Hiltebrant) allowed Franciscans to found an abbey in Kursa (Latin: Curonia). Since 1484 northwards from Hasenpoth (Latvian: Aizpute) the Monastery of St. Clarissa (burnt down in 1523) was formed for Franciscan nuns $[15,57]$.

\section{Conclusions}

1. In Livonia and in the State of the Teutonic Order, Dominican and Franciscan monasteries were founded in towns, affected the medieval construction. The Riga Archbishopric Centre building complex consisted of two yards - the bishop's yard with a perimeter construction and the Canonical Chapter's yard with the Dominican abbey's building complex, in which the cathedral was included. In Riga, in Dominican monastery the chancel of St. John the Baptist's Church was deep, for it partly occupied the place of the bishop's residence chapel. In the Old Town of Kulm the Dominican's monastery St. Peter and St. Paul's Church and in the New Town of Thorn the triple-nave St. Nikolay's Church had an 
asymmetric two-nave hall covered with a ridged roof. A deep chancel with a polygonal closing to which in the north the sacristy was built. In the eastern side the slightly shorter south nave, where there were secondary worship places, was closed with a polygonal chapel (Polish: kaplica św. Jacka). The abbey's rooms were placed on the north side.

2. In Livonia and the State of the Teutonic Order, Franciscan monasteries was usually allocated near the defensive wall of the town. In fortified Braunsberg the Franciscan monastery with the church were situated in the north-west corner of the town's defensive wall. The corner tower was included in the monastery's building complex. In the western part of the Old Town of Kulm the triple-nave St. Jacob and St. Nikolay's Franciscan Church had a deep chancel, to which a tower was built on the south side. Monastery's buildings were placed northwards from the church. Also in Riga, the triple-nave St. Catherine's Church had an elongated chancel and monastery's buildings were arranged northwards from the church.

\section{References}

1. Caune, A. Ose, I. (2010) Latvijas viduslaiku mūra baznīcas. 12. gs. beigas - 16. gs. sākums. Enciklopēdija. Rīga: Latvijas vēstures institūta apgāds, 511 lpp. ISBN 978-9984-824-17-8. [In Latvian]

2. Caune, A., Ose, I. (2004) Latvijas viduslaiku pilis, IV. Latvijas 12. gadsimta beigu-17. gadsimta vācu piḷu leksikons. Rīga: Latvijas vēstures institūta apgāds, 591 lpp. ISBN 9984-601-07-2. [In Latvian]

3. Dehio, G., von Bezold, G. (1887-1901) Kirchliche Baukunst des Abendlandes. Stuttgart: Verlag der Cotta'schen Buchhandlung, [In German]

4. Heinrici Chronicon, (1993) Rīga: Zinātne, 453 lpp. ISBN 5-7966-0326-4. [In Latvian]

5. Jansons, G. (2001) Daži mazāk pazīstami seno mūra celtṇu fragmentu atradumi Vecrīgas apbūvē. In: Senā Rīga. Rīga: Latvijas vēstures institūta apgāds, 113.-142. lpp. ISBN 9984-601-75-7. [In Latvian]

6. Kranz-Domaslowska, L. (2013) Double cities in the Teutonic state on the example of Toruń. In: RIHA Journal 0068, 8 March 2013.

7. Nawrocki, Z.(1966) Pofranciszkański kościół NMP w Toruniu. Próba rekonstrukcji dziejów budowy. In: Zeszyty Naukowe Uniwersytetu Mikołaja Kopernika, Zeszyt 21, Zabytkoznawstwo i Konserwatorstwo 2. Poznań: Państwowe Wydawnictwo Naukowe, 1966, 47. - 80. lpp. [In Polish]

8. Misāns, I., Šnēê, A. (2004) Klosteris, pils un pilsēta. Materiāli semināriem Rietumeiropas viduslaiku vēsturē. Rīga: Latvijas Universitāte, 288 lpp. ISBN 9984-770-19-2. [In Latvian]

9. Ranisch, B. (1695) Beschreibung aller Kirchen-Gebäude der Stadt Dantzig. Danzig: Raths und Gymnasii Buchdruckern, Johann Zacharias Stollen. (Universitäts- und Landesbibliothek Sachsen-Anhalt - ULB) [In German]

10. Steinbrecht C. (1885) Die Baukunst des Deutschen Ritterordens in Preußen. Verlag von Julius Springer, 1885-1920. Band 1: Thorn im Mittelalter. Berlin.

11. Šterns, I. (1997) Latvijas vēsture. 1290-1500. Rīga: Apgāds Daugava, 741 lpp. ISBN 9984-531-50-3. [In Latvian]

12. Toman, R., Bednorz, A., Borngässer, B. (2015) Cathedrals and Churches of Europe. Potsdam: h. f. ullmann publishing GmbH, 400 lpp. ISBN 978-3-8480-0690-8.

13. Tuulse, A. (1942) Die Burgen in Estland und Lettland. Dorpat: Dorpater Estnischer verlag, 432 s. [In German]

14. Wünsch, C. (1960) Ostpreussen. Deutscher Kunstverlag, 100 S. [In German]

15. Zandberga, R. (1980) Aizputes arhitektoniski pilsētbūvnieciskās struktūras attīstības vēsture. Rīga: Latvijas PSR Kultūras ministrijas Kultūras pieminekḷu restaurēěanas projektēšanas kantoris, 31. lpp. [In Latvian]

16. Zilgalvis, J., Levina, M. (2007) Svētās Katrīnas baznīca. In: Rīgas dievnami. Arhitektūra un māksla. Rīga: Zinātne \& Mantojums, 328. - 335. lpp. ISBN 978-9984-823-00-3. [In Latvian]

17. Zucconi, G. (2007) Firenze guida all'architettura. Verona: Arsenale Editrice, 147 lpp. ISBN 978-88-7743-146-2.

18. Чинг, Ф. Д. К. (2011) Всемирная история архитектуры. Сооружения всех стран и континентов за 6000 лет: от IV тысячелетия до н. э. до наших дней. Москва: Астрель, 784 с. ISBN 978-5-271-35405-2. [In Russian]

\section{INFORMATION ABOUT AUTHOR:}

Silvija Ozola, Mg. arch, Assistant Professor of Riga Technical University (RTU), Latvia. Graduated the Faculty of Building at Riga Polytechnic Institute, obtained a certificate in the architecture in 1980. Obtained the diploma of Education and Sport specialist at Latvian Academy of Sport Education in 2003. Obtained a master degree in architecture at RTU the Faculty of Architecture and Urban Planning in 2008. Graduated a doctor degree of Architecture theoretical course of study at RTU the Faculty of Architecture and Urban Planning in 2010. Academic work experience: lecturer at Riga Building College (2005-2010), lecturer at RTU (2006-2016); Assistant Professor at RTU since 2016. Professional work experience: architect at Design Institute „Lauku projekts” („Rural Project”) (1980-1983); architect at Architect's Design Group in Liepaja District (1984-1990). The author of village development projects, as well as projects of public and private buildings. The author of more than 80 publications about landscape architecture, urban planning, history of architecture, published in Latvia, Estonia, Poland, USA, Italy, Germany, Russia. Research interests - art, music, landscape architecture, urban planning, history of architecture. E-mail: ozola.silvija@inbox.lv

Kopsavilkums. Pilsētās nebija lūgšanu vietas, un iedz̄ivotājiem bija jāpārvar lieli attālumi, lai nokḷūtu klostera baznīcā ārpus pilsētas. Augustīniešu kanoniķis Domenico di Guzmán (1170-1221) un daži mūki Tulūzā 1214. gadā dibināja relig̣isku organizāciju Sprediḳotāju (latịnu: praedicatores) jeb Brāḷu Dominikāṇu ordeni 
(latīṇu: Ordo Praedicatorum), kam nedrīkstēja piederēt laicīgais īpašums. Dominikāṇi netiecās pēc noslēgtības, darbojās pilsētās, kur ierīkoja klosterus, centās iegūt iespējami vairāk piekritēju, aprūpēja par nabagus un slimos. Cilvēki guva garīgu spēcinājumu. Uzskatīja, ka klosteriem bagātības nav vajadzīgas: mūkiem iztika jānodrošina ar darbu, taču, ja ar to būtu nepietiekami, tad jāubago. Dominikāṇiem neatḷāva celt par trīsdesmit pēdām augstākas baznīcas un veidot akmens arkas, izṇemot virs altārdaḷas un sakristejas. Baznīcas cēla pilsētnieki, pārbūvējot pat šķūņus. Mūku-ubagotāju klosteri ieņēma viduslaiku pilsētu apbūvē arvien nozīmīgāku vietu. Romā, Aventīna kalnā iesvētīja dominikāṇu galveno dievnamu - Santa Sabina all'Aventino baziliku. Kulmas Vecpilsētā dominikāṇi, iespējams, ieradās 1233. gadā, ierīkoja klosteri un sāka būvēt Sv. Pētera un Sv. Pāvila baznīcu (poḷu: kościót św. Piotra i św. Pawta w Chetmnie), kuru pabeidza 13. gs. 4. ceturksn̄̄. Tornas Jaunpilsētā dominikāṇu mūki ieradās 1263. gada 2. aprīl̄̄ un, Kulmas bīskapa finansiāli atbalstīti, uzcēla klostera (poḷu: Ojców Kaznodziejów św. Dominika) kompleksu, ko papildināja Jaunpilsētā lielākais dievnams - trīsjomu Sv. Nikolaja baznīca (poḷu: kościół św. Mikołaja i klasztor dominikanów; 1334, nojaukta 19. gs. vidū) ar dzil̨u altārtelpu (1334-1343), kurai bija poligonāls noslēgums. Elbing (poḷu: Elbląg) Vecpilsētā dominikāṇu klosteris (vācu: Dominikanerkloster; 14. gs.) atradās aizsargmūra ziemel̦rietumu stūrī. Rīgā laikā starp 1211. un 1215. gadu sāka būvēt bīskapa otro sētu ar palasu, otro Domu jeb Sv. Marijas baznīcu un klosteri Domkapitulam. Otrais Rīgas bīskaps (1229-1253) Nikolaus von Nauen (latīnu: Nicolaus Canonicus Rigensis) bīskapa pirmo sētu ar mūra mītni, kas, iespējams, cieta 1215. gada 4. marta ugunsgrēkā, un tai piederīgos zemesgabalus 1234. gada 8. septembrī dāvāja dominikāṇiem, lai viṇi apmestos pie Rīdziņas (vācu: Rising) un Līvzemē sludinātu kristietību. Dominikāṇi dibināja klosteri (1234), kur Sv. Jāṇa Kristītāja baznīcas un ēku izkārtojums nocietinātajā teritorijā veidoja funkcionālu dalījumu un pagalmu. Pāvests 1425. gadā piešķīra dominikāņiem tiesības uz nekustamo īpašumu.

Akonā misionāra darbu 1211. gadā sāka itāḷu dzejnieks Giovanni Francesco di Pietro di Bernardone (1182-1226), kurš, sekojot aicinājumam kḷūt par katolu mūku, atteicās no materiāliem labumiem, lai dzīvi veltîtu Dievam. Viṇš dibināja Franciskāṇu ordeni un sarakstīja Regula bulata, kuru pāvests apstiprināja 1223. gadā. Itālijas pilsētā Asīzē, kur moceklim, bīskapam Rufino (3. gs.) 1140. gadā sāka celt arhitekta Giovanni da Gubbio projektēto San-Rufino katedrāli (itāḷ: Cattedrale di Assisi; 1140-1253), Franciscus Assisiensis un Clara Assisiensis (1193-1253) 1212. gada 18. martā dibināja nabadzīgo māsu Svētās Klāras ordeni (latīnu: Ordo Sanctae Clarae). Franciscus Assisiensis tika kanonizēts, un Asīzes Sv. Konventa klosterī (itāḷu: Il Sacro Convento di San Francesco in Assisi) 1228. gada 17. jūlijā ielika pamatakmeni vienjoma Sv. Franciska bazilikai (itāḷu: la Basilica di San Francesco d'Assisi). Pakalnā izveidoja divstāvu celtnes redzamo daḷu, bet apakšējo daļu ar kapelām un kriptām ieskāva klosteris. Franciskāṇu galvenā baznīca ieguva Basilica majoris statusu. Florencē 1294. gada 12. maijā senākas baznīcas vietā sāka celt arhitekta Arnolfo di Cambio (1240-1300/1310) projektēto, iespējams, Itālijā lielāko franciskāṇu klostera dievnamu - T-veida plānojuma Svētā Krusta baziliku (Italian: Basilica di Santa Croce; 1294-1385), kuras plānam ir līdzība ar senākās Basilica Vaticana plānu Romā. Pāvests (1431-1447) Eugenius IV baznīcu 1442. gadā iesvētīja. Baskājiem jeb minorītiem (latīṇu:minoritae, fratres minores) aizliedza privātīpašumu un kopīpašumu. „Ubagotājmūku ordeṇiem” nebija naudas, tādēḷ bija jāiztiek no labprātīgiem ziedojumiem. Pilsētnieki viṇiem sākotnēji cēla ḷoti vienkāršas baznīcas. Dancigā pie tirgus franciskāṇi uzcēla Sv. Katrīnas baznīcu (poḷu: kościót św. Katarzyny; 1227-1239), dibināja Sv. Brigitas māsu klosteri (vācu: St. Brigitten-Büßerinnen-Kloster zu Danzig) un sāka būvēt Sv. Brigitas baznīcu (poḷu: kościót św. Brygidy; ap 1350). Kulmas zemē franciskāṇi pirmo konventu (1239) ierīkoja uz ziemeḷietumiem ārpus Tornas Vecpilsētas, kur 13. gs. vidū uzcēla taisnstūra plānojuma baznīcu, kuru paplašināja (1350-1370): izveidoja ar divslīpu jumtu segtu trīsjomu Vissvētākās Jaunavas Marijas Debesbraukšanas baznīcu (poḷu: kościół Wniebowzięcia Najświętszej Marii Panny, 1270-1300, 1557-1724, 17241821) bez galvenā torṇa, taču ar asimetrisku zāli un šauriem logiem. Altārdaḷas būvapjomu papildināja trīs astoṇstūra plānojuma torṇi, no kuriem vidējais bija lielāks. Kulmas Vecpilsētas rietumdaḷā senākas baznīcas vietā franciskāṇi uzcēla trīsjomu zāles Sv. Jēkaba un Sv. Nikolaja baznīcu (poḷu: kościót św. Jakuba i św. Mikołaja; 1326) ar taisnstūra altārdaḷ, kurai dienvidpusē piekḷaujas tievs astonsstūra plānojuma tornis. Galveno jomu pārsedza ribotas velves, bet šaurās sānejas - zvaigžņu velves. Klostera ēkas izvietoja uz ziemel̦iem no baznīcas. Aizsargmūra ietvertajā Braunsbergā franciskāṇi klostera ēku kompleksu (1296) ar baznīcu uzbūvēja pilsētas ziemel̦rietumu stūrī. Rīgā, kur franciskāṇi bija sastopami kopš 1233. gada, klostera mūra baznīca atradās zemesgabalā, domājams, Domkapitula sētas vietā pie Rīgas aizsargmūra netālu no vārtiem, pa kuriem nokḷuva Daugavas (vācu: Düna) labā krasta pietekas Rīdziņas piekrastē. Sv. Katrīnas franciskāṇu klosteris pirmo reizi minēts 1258. gadā. Klostera sētas ziemeḷdaḷu ar senākām celtnēm - kapelas (13. gs. 1. puse) un, iespējams, vecā refektorija - no dienvidpusē ielas malā uzceltās trīsjomu zāles Sv. Katrīnas baznīcas, kuru izmantoja arī pilsētnieki, pagalmu noškīịa krusteja, radot funkcionāli dažādu divdalījuma plānojumu. Krustejas apņemtā klostera pagalma austrumpusi noslēdza refektorijs ar dormitoriju un kapitula zāle. Klostera ieejas vārti veda pagalmā, kur 1330. gadā uzbūvēja stallıus ar sardzes eju. Franciskāṇu klosteri bija visās Rīgas arhibīskapijas pilsētās: Limbažu priekšpilsētā uz ziemeliem ārpus pilsētas mūriem 1466.-1472. gadā uzcēla klosteri un mūra baznīcu, Kokneses pilsētiņas austrumpusē netālu no aizsargmūra bija katoḷu klostera baznīca ar torni. 